\title{
12
}

\section{Landscape linkages and biodiversity in European landscapes}

\author{
Rob Jongman
}

\begin{abstract}
Linear features are structuring landscape elements. We change our landscapes and rebuild them into new linkages, and landscapes are even constructed around these linkages. Landscape linkages are important for species migration and dispersal on a large scale and a small scale: storks, bats and badgers. There is, however also diversity within landscapes and landscape elements: plants species, insects and breeding birds.

History and land-use development hampered both biodiversity at the European level and at the landscape level. As landscapes are dynamic, cultural landscapes are not only historic, but they will be constructed and reconstructed. History has had an impact on the regional diversity.

Reconstructing European linkages should take into account large-scale structures and ecosystems such as mountain ranges, wetlands, forests and rivers and small-scale structures such as hedgerows, ponds, stonewalls and small forests. Landscape construction is not a simple making of landscape elements. The reconstruction of biodiversity is much more complex as it does not seem to return so easily.

We can learn from European experiences and exchanges that it is important to exchange and share experiences and disseminate results. To link the different aspects of landscape planning and the conservation of landscape diversity requires interdisciplinary research programmes.
\end{abstract}

Keywords: biodiversity; landscape diversity; species dispersal; homogenization; fragmentation

\section{Introduction}

The history of planning of landscape structures such as urban park systems already started over a century ago. They show that people have valued linkages and linear structures. Roads and linkages can be used to go somewhere and can help expand your living environment. Corridors, lanes and streams are transport routes but also give landscapes their character. Architects emphasize these structures. Already in the nineteenth century in large cities the main axes of towns were developed into green boulevards, such as the Champs Elysées in Paris and the footpaths along the Seine in Paris (Searns 1995). The Champs Elysées in Paris and the Ramblas in Barcelona (originally a temporary river system) let you recognize where you are. In the USA Frederik Law Olmsted developed in 1860 plans for Brooklyn and Boston to

\footnotetext{
\# Alterra Green World Research, Postbox 47, 6700 AA Wageningen, The Netherlands. E-mail: rob.jongman@wur.nl
} 
solve the water-drainage problems and to link the urban parks and quarters by green corridors, the 'parkways'.

Also the rural areas have their linear features. When you walk through the stonewall landscapes of England you know that you are somewhere on the British Isles or in Ireland. Long lines of cypresses remind of Italy and roads with heavy linden trees are found in the northern parts of Germany, in Poland and Estonia; roads with fruit trees are characteristic for Bohemia, Moravia and parts of Austria. The stonewalls in the landscapes of the Mani on the Peloponnesus have similarities with those in Britain and Ireland, but their history and landscape setting let you recognize them as different landscapes: the vegetation is dry, the climate is hot, the mountains are rough and the land is less cultivated. If you look in detail to, for instance, hedgerows, you can distinguish between the hedgerows of Ireland with hawthorn and fuchsia, and the hedgerows of the Pleistocene sands of the European lowlands along the North Sea, where birch and oak dominate.

Linear features are structuring elements. We are always developing new landscape structures. We change our landscapes and rebuild them to our wishes and to our needs; we build new linkages, and landscapes are even constructed around these linkages. Landscapes are becoming car landscapes (Ibelings 1999) or 'Mc Donald's' landscapes (Van Beusekom 1999). However, not only humans use landscape linkages; also plants and animals move through landscapes in their own way. Also they need their landscape linkages to move from one suitable habitat to another, on a short distance along a hedgerow or over a long distance from Northern Europe to Western Africa.

The question I will discuss here is that there is a difference between the ecological functioning of linkages in our landscapes for biodiversity and the biological diversity within landscape linkages. The latter are due to differences in history and policy and the message for the modern landscapes.

\section{Theoretical considerations on migration}

There is much emphasis within society for maintaining linear structures; in several countries regulations and subsidies exist; for instance in The Netherlands, in England, Denmark for hedgerows and in Spain for the drove roads. Are these linear structures so important for society and for nature?

Lovelock stated in his work on Gaia (1979) that the most important property of the earth as Gaia is the tendency to keep a constant condition for all life systems. Provided that we have not yet seriously interfered with her status of homeostasis this tendency should be as predominant now as it was before man's arrival on this planet. A second statement is that the impact of what we do to this planet may depend greatly on where we do it. The message of these statements is that interference with the functioning of life on earth may have an impact also somewhere else and the consequences are difficult to estimate. Changes in one place might influence processes in the world in which we and other species have to live. Lovelock discusses energy and matter production such as the balance in the air and the sea. However, he does not discuss what kind of interference might be important for species that we interfered with in the past and shall interfere with increasingly in the future.

Exchange of species and genotypes of species is important for development of new varieties and new species. According to the classical study of Stebbins and Major (1965) on speciation and endemism in the Californian flora, abiotic and climatic diversity stimulate speciation especially in ecological gradients, where ecosystems are 
dynamic and exchange of genes can take place. According to Runemark (1969) and Greuter (1979) it must be stated that plants in a naturally stable environment do not show much development.

Can we apply theories of Lovelock on the one hand and of Stebbins and Major on the other hand, and can we fit them into a European context? We are living here with 350 million people, and we have an impact on species decline in the world by exterminating them and by changing, diminishing and fragmenting their habitat. Europe has been cultivated for about 2000 years and we have changed and structured it. We have made our landscapes static and frozen it in fixed human-oriented patterns. We constructed corridors and we made barriers for exchange. The consequence was that we made natural processes and species abundance decline in many places, but also that we linked isolated natural elements.

Due to the process of land cultivation in the past centuries Europe lost its larger natural areas and the fauna that belongs to them, and this process is still ongoing. The Spanish pardel lynx (Lynx pardina) is now nearly extinct. Europe lost its naturalness on the continental level, but maintained a fine-grained cultural landscape and large areas with monotonous agricultural land instead. We see the same happening elsewhere in the world. In Northern Argentina there are three remnant jaguar populations of totally 25 animals dispersed over three national parks $40-60 \mathrm{~km}$ apart. They will not survive in isolation.

Migrating species are not all year available to signal the importance of a site as a temporary habitat in their migration. European storks (Ciconia ciconia) for instance breed in central Europe and they winter in Africa, migrating 10,000 km each season (Goriup and Schulz 1990). The breeding population is mainly concentrated in Germany, Poland, the Czech Republic, Slovakia, Hungary and the Baltic States in the East and in Spain and Portugal in the West. They are birds of cultural landscapes of Europe. They are highly valued by mankind and are symbols of fertility. Their populations used to cover a larger area, but their breeding success was severely hampered by land-use changes in the last decades and problems in their migration routes. Other species such as sturgeons and salmons use rivers to migrate. Bats, badgers and forest birds use hedgerows and small forests to migrate from one place to another for foraging and dispersing.

Cultural landscapes as well as old towns are expressions of our culture from the past, with regionally characteristic elements such as terraces, pollards, field structures, avenues, hedgerows and stonewalls. They have functional, scenic, cultural and natural and recreational values. Stork nests are maintained, even when storks have disappeared from a region. That is not a natural value but a cultural value. And as such they are worth to be maintained. They are low-dynamic systems representing the traditional landscapes of Europe, its culture and its products. They preserve our culture and part of our nature.

We have to accept that we live in a part of the world with many people, that we have completely changed our landscape from natural to cultural from forest to agriculture. This also means that we exterminated species that are dependent of mature forests and larger natural areas and favoured those that are adapted to our cultural landscapes: meadow birds, small mammals, meadow plants such as orchids and other herbs. Finally it might be so that by making the land inaccessible for natural species we cause genetic erosion among the surviving populations and stop potential adaptation to future living conditions. 


\section{Occurrence and diversity of landscape linkages}

Linear features in cultural landscapes have values for mankind. Corridors and linkages are essential. In human history these used to be church roads, waterways, Roman roads, Napoleonic roads, transport routes from the Netherlands to St. Petersburg and more. We still recognize them in our present-day landscapes. Their density and spatial arrangement change according to the type of land use. Their connectivity varies from high to low depending on their spatial arrangement, internal structure and management. They are multifunctional by definition; they have both socio-economic functions and ecological functions. Especially the socio-economic functions have a culturally determined value. However, also natural values in cultural landscapes are determined by social backgrounds of a region.

There is a relationship between cultural-historical and biodiversity aspects of landscape structures, and this might especially be seen in the diversity of linear structures. In a comparative study between adjacent regions in the Pleistocene sand area of Germany and The Netherlands (Grafschaft Bentheim and Twente, respectively) we made a comparison of diversity in species number on the basis of landscape structures (hedgerows, wooded banks; Table 1) and vegetation (plantcommunity types). Data have been collected in a stratified random sample in both areas (Dirks and Terpstra 1995). The first stratification was between The Netherlands and Germany and has further been made on the basis of soil types.

The results showed a significant difference in species diversity on both sides of the border. The German part had less species diversity in landscape elements than the Dutch part. Tables 2 and 3 indicate that there are differences in the way landscapes have been developing. In comparable environmental conditions landscapes developed differently in two adjacent areas. In The Netherlands (Twente) small-scale landscapes dominate; in Germany (Bentheim) the landscape types are more evenly distributed. In The Netherlands on the rich soils, where species-rich Carpinion forests can occur, linear features are absent. Still, in Twente the plant species diversity is higher for the landscape elements and it is also more dominated by small-scale landscapes.

We did not look at the causes yet, but the conclusion might be that not only physical differences but also, in the past, culture and the policy situation have determined the structure of the cultural landscape. Policy and historical processes in the development of land-ownership have determined what types of landscapes developed. Regional history and policy had an impact in the past and they will continue to have it.

Table 1. Number of plant species in Twente (The Netherlands) and Grafschaft Bentheim (Germany)

\begin{tabular}{|l|c|c|c|}
\hline & The Netherlands & Germany & Total \\
\hline Forest & 108 & 107 & 138 \\
\hline Wooded banks & 131 & 109 & 150 \\
\hline $\begin{array}{l}\text { Forest + Wooded } \\
\text { banks }\end{array}$ & 162 & 142 & 191 \\
\hline
\end{tabular}


Table 2. Number of sample plots of different vegetation types in forests in Twente (The Netherlands) and the adjacent part of Grafschaft Bentheim (Germany) subdivided for small-scale, large-scale, mixed and forest-dominated landscapes. In both Twente and Bentheim 55 sample plots have been made

\begin{tabular}{|c|c|c|c|c|c|c|c|c|}
\hline & \multicolumn{4}{|c|}{ Twente } & \multicolumn{4}{|c|}{ Bentheim } \\
\hline & $\begin{array}{l}\text { Small- } \\
\text { scale } \\
\text { landscape }\end{array}$ & $\begin{array}{l}\text { Large- } \\
\text { scale } \\
\text { landscape }\end{array}$ & $\begin{array}{l}\text { Mixed } \\
\text { landscape }\end{array}$ & $\begin{array}{l}\text { Forest } \\
\text { landscape }\end{array}$ & $\begin{array}{l}\text { Small- } \\
\text { scale } \\
\text { landscape }\end{array}$ & $\begin{array}{l}\text { Large- } \\
\text { scale } \\
\text { landscape }\end{array}$ & $\begin{array}{l}\text { Mixed } \\
\text { landscape }\end{array}$ & $\begin{array}{l}\text { Forest } \\
\text { landsc } \\
\text { ape }\end{array}$ \\
\hline $\begin{array}{l}\text { Alno- } \\
\text { Padion } \\
\end{array}$ & 7 & 1 & 1 & & 6 & & & \\
\hline $\begin{array}{l}\text { Fago- } \\
\text { Quercetu } \\
\text { m/Alno- } \\
\text { Padion }\end{array}$ & 7 & 1 & 1 & & 2 & 1 & 1 & \\
\hline $\begin{array}{l}\text { Fago- } \\
\text { Quercetu } \\
\mathrm{m} \\
\text { Rich }\end{array}$ & 1 & 1 & & & 2 & 3 & & \\
\hline Carpinion & 2 & & & & 2 & 1 & 1 & 1 \\
\hline $\begin{array}{l}\text { Fago- } \\
\text { Quercetu } \\
\mathrm{m} \\
\text { Poor }\end{array}$ & & 1 & & & & 1 & 1 & \\
\hline $\begin{array}{l}\text { Vaccinio- } \\
\text { Piceetea, } \\
\text { humid }\end{array}$ & 9 & 4 & 4 & & 5 & 2 & 2 & \\
\hline $\begin{array}{l}\text { Vaccinio- } \\
\text { Piceetea, } \\
\text { dry }\end{array}$ & 2 & 1 & 10 & & 2 & 10 & 10 & 2 \\
\hline Total & 28 & 9 & 16 & 0 & 19 & 18 & 15 & 3 \\
\hline
\end{tabular}

Table 3. Number of sample plots of different vegetation types in landscape elements in Twente (The Netherlands) and the adjacent part of Grafschaft Bentheim (Germany) subdivided for small-scale, large-scale, mixed and forest-dominated landscapes. In Twente 51 and in Bentheim 52 sample plots have been made

\begin{tabular}{|l|l|l|l|l|l|l|l|l|}
\hline & \multicolumn{4}{|c|}{ Twente } & \multicolumn{4}{c|}{ Bentheim } \\
\hline & $\begin{array}{l}\text { Small- } \\
\text { scale } \\
\text { landscape }\end{array}$ & $\begin{array}{l}\text { Large- } \\
\text { scale } \\
\text { landscape }\end{array}$ & $\begin{array}{l}\text { Mixed } \\
\text { landscape }\end{array}$ & $\begin{array}{l}\text { Forest } \\
\text { landscape }\end{array}$ & $\begin{array}{l}\text { Small- } \\
\text { scale } \\
\text { landscape }\end{array}$ & $\begin{array}{l}\text { Large- } \\
\text { scale } \\
\text { landscape }\end{array}$ & $\begin{array}{l}\text { Mixed } \\
\text { landscape }\end{array}$ & $\begin{array}{l}\text { Forest } \\
\text { landsc } \\
\text { ape }\end{array}$ \\
\hline $\begin{array}{l}\text { Fago- } \\
\text { Quercetu } \\
\mathrm{m}\end{array}$ & 5 & 6 & 5 & & 3 & 5 & 3 & \\
\hline $\begin{array}{l}\text { Alno- } \\
\text { Glutinosa } \\
\mathrm{e}\end{array}$ & 10 & 3 & 6 & & 12 & 11 & 8 & \\
\hline $\begin{array}{l}\text { Alno- } \\
\text { Padion }\end{array}$ & 13 & & 1 & & 2 & 1 & & \\
\hline $\begin{array}{l}\text { Carpino- } \\
\text { Berberidi- } \\
\text { on }\end{array}$ & & & & & 3 & 1 & 1 & 2 \\
\hline Total & 28 & 9 & 12 & 0 & 20 & 18 & 12 & 2 \\
\hline
\end{tabular}




\section{Ongoing changes, homogenization and fragmentation}

Changes in the European landscapes are consequences of the processes in society under the influence of global processes, developments in the world market, changes in food demand, demographic trends, agricultural production and other land-use changes. Production moves from one region to another, agricultural land becomes forest and forested land becomes agriculture. Forests of exotic species are planted. Through changes in agriculture and forestry practices, landscapes have suffered rapid and often irreversible changes. These changes can be classified as polarization of land uses, partly through marginalization, partly through intensification. This results in a homogenizing landscape (Fry and Gustavsson 1996).

Intensifying agriculture makes land monofunctional and takes away both cultural and natural diversity. Intensification by one farmer - reducing production costs - will improve his position on the market. Also, here we have to realize that the farming market is international within the European Union and elsewhere. The Greek farmers have to compete with the Dutch and the Danish farmers on the cheese market, and as we can see through the development of BSE and foot and mouth disease also the trade in animal stock is international.

Both intensive and extensive land use are expressed in the landscape: the structure of the land, the size of the parcels and the area and the diversity of natural and seminatural vegetation that is present. At present the pressure of economic competition in farming, forestry and urbanization makes the land partly homogenizing by disappearance of regional differences in (semi-)natural features. This is not a new process but its features become more and more recognizable. We live in a homogenizing world, and that has its consequences.

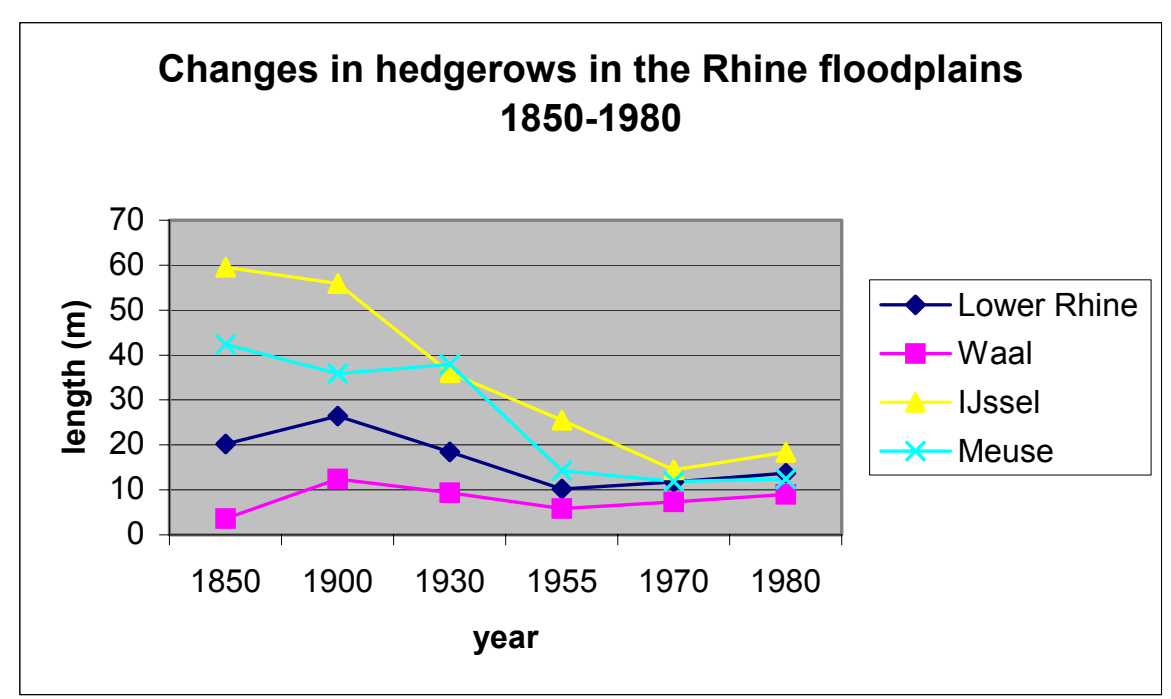

Figure 1. Mean changes in hedgerows of the floodplains of the Dutch Rhine and Meuse system in $\mathrm{m} / \mathrm{ha}$ (Jongman and Leemans 1982)

The multifunctionality of the landscape is disappearing; although outdoor recreation and nature conservation are becoming more important, they get fewer opportunities. We can see this process for some decades in the European landscapes. We see the decline in landscape diversity through the structure in the landscape that makes coherency disappear (Table 4). Examples can be found everywhere. In The Netherlands, from 1900 to 1980 forests in the floodplains decreased by $90 \%$ and 
hedgerows by $80 \%$ (Figure 1). In the period 1950-1990 all the open side channels along the major branch of the Rhine have disappeared (Jongman 1992). But this did not only happen in The Netherlands. In the Czech Republic the natural plantings in the cultural landscapes disappeared nearly completely during the collectivization process. We can see the same process happening in the UK and France but then in a setting of the free market.

Moreover, this is not the only process that is going on. In the urban fringe of cities in Western Europe intensive agriculture used to be an important land use. Now its role is strongly diminishing, other functions take over, such as horse keeping, garden centres and recreation facilities (Lucas and Van Oort 1993). A comparable trend can be seen elsewhere in Europe, from Lisbon to Moscow. In the competition with urban functions rural functions mostly cannot survive. The landscape develops into a new diversity of artificial elements causing fragmentation of natural features that can be considered negative landscape diversity (Table 4). For small animal species roads are often inaccessible barriers, and that means that they should find new living space within the area they are confined to. Some animals like amphibians in spring take the risk of crossing roads towards breeding ponds. They are only successful in areas with low-density traffic or with the help of volunteers bringing them to the other side. Larger animals will be hampered in their movements by urban areas, roads and ecologically unattractive lands unless ecoducts and passovers are built (Smith in press). For fish the situation in most European rivers is even worse: dams and sluices have become unsurpassable barriers and mostly fish ladders are lacking.

Fragmented and diverse landscapes are characterized by both small scale and the presence of many landscape elements. A fragmented landscape, however, differs from a diverse landscape by the fact that the structures in the land are not linkages but barriers. Transport infrastructure in Europe (roads, waterways and railways) is the clearest in this aspect. They can only be used by cars and moreover they intersect habitats of species and decrease the possibilities of species to disperse between different habitats. Urbanization, agriculture and industry have put an increasing pressure on the functioning of landscape and nature.

Table 4. Examples of land-use processes causing ecological homogenization and fragmentation in the European landscapes

\begin{tabular}{|l|l|l|l|}
\hline Homogenization & Fragmentation \\
\hline Activity & Impact & Activity & Impact \\
\hline $\begin{array}{l}\text { Intensification of } \\
\text { forestry and } \\
\text { agriculture }\end{array}$ & $\begin{array}{l}\text { Larger uniform fields } \\
\text { and forest plots: less } \\
\text { accessible }\end{array}$ & River regulation & $\begin{array}{l}\text { Hampering river } \\
\text { migration and river } \\
\text { transport }\end{array}$ \\
\hline Urbanization & $\begin{array}{l}\text { Larger built-up } \\
\text { areas: barriers }\end{array}$ & River canalization & $\begin{array}{l}\text { Hampering } \\
\text { crossing rivers due } \\
\text { to structure change }\end{array}$ \\
\hline $\begin{array}{l}\text { Mechanization and } \\
\text { fencing }\end{array}$ & $\begin{array}{l}\text { New barriers and } \\
\text { disappearance of } \\
\text { landscape elements }\end{array}$ & Forest production & $\begin{array}{l}\text { Dissecting forests } \\
\text { in different age } \\
\text { stands and forest } \\
\text { types }\end{array}$ \\
\hline $\begin{array}{l}\text { Land } \\
\text { abandonment }\end{array}$ & Larger natural areas & $\begin{array}{l}\text { Transport } \\
\text { development }\end{array}$ & $\begin{array}{l}\text { Causing barriers in } \\
\text { the landscape }\end{array}$ \\
\hline
\end{tabular}


Fragmentation of natural areas is a spatial problem that can be defined as the dissection of the habitat of a species in a series of spatially separated fragments. Fragmentation leads to diminishing habitat area and an increase in barriers or spatial discontinuity. Fragmentation is caused by barriers such as roads, urban areas and inaccessible agricultural land, but also by the continuing decrease of landscape elements (small forests, hedgerows, riparian zones).

In ecological sense isolation is an important feature in agricultural landscapes of Northwestern Europe. But also in production forests, management can cause isolation of the remnants of natural old-growth forests within them (Harris 1984). Most natural and semi-natural habitat sites are remnants of a former natural area. Present landscapes are dominated by man-made dynamic habitats and the less dynamic habitats are small and isolated, as are the populations in them. Habitat isolation and habitat loss prevent natural species to develop viable populations or let populations survive on different equilibrium levels (Hanski et al. 1995). Natural relations have declined by the disappearance of forested corridors and natural river corridors and the development of human infrastructure. It can be expected that these processes of homogenization and fragmentation will increase in this century. The strategy to overcome this is the redevelopment of ecological coherence through networks and ecological corridors in the same way as we construct road networks. This has important consequences for all land use and land-use planning.

\section{Making new European landscapes}

Developments go fast. We cannot look far into the 21 st century. Still we can detect some important trends and issues. We see the new developments; some parts of our countryside remain what they have been, the small-scale cultural landscapes. Other parts, however, will develop further into the urban, suburban and transport landscapes and even landscapes for nature conservation: the new European landscapes. Some of them will be relatively stable, other ones will be dynamically changing.

The changes that we cause are twofold:

- We recreate or destroy connectivity by making barriers, mitigating landscape connectivity through fish ladders, ecoducts and passovers

- We recreate or destroy the internal biodiversity of the landscape elements by clearing landscape elements and replanting or reconstructing landscape elements.

Where we have destroyed connectivity at the European or regional scale, we have the obligation to rebuild it or make it possible that they function again as ecological corridors. The large mountain ranges, the large European rivers are the major corridors at the European scale. They must be taken care of as European ecological linkages, next to their other functions. But this is not only important for natural systems. The new urban, suburban and transport-dominated landscapes will also have to include ecological functions. They will have to combine housing and transport with natural connectivity. The European ecological networks as proposed in recent years should be balanced with these more dynamic land uses (Bischoff and Jongman 1993; Bouwma, Jongman and Butovsky 2002).

Landscape diversity and diversity within landscapes and landscape elements depend very much on the seed banks within them, the ecosystems and species within the landscape. Constructing landscape elements does not mean that landscape diversity and regional or local biodiversity is automatically maintained. Construction of a motorway or an urban area, or the reconstruction of an agricultural area might mean that species are destroyed and soil and water conditions changed so much that the local biodiversity 
will not be maintained. As shown in the Rhine floodplains the return of plant species after recultivation of clay-extraction areas did not occur even in a period of forty years, although seed transport through the river was guaranteed (Jongman 1992). This means that besides ecological engineering natural conditions are important.

However, these challenges can only be tackled by careful planning and design. Europe only has minor natural developments. Nature and the landscape structure of the new landscapes have to be planned and constructed and barriers of other natural functions have to be considered opportunities for smart design that also allow genetic exchange as far as possible and allow movement of species to adapt changing environmental conditions. Landowners and the general public will have to participate in the planning process as they participated in the land management in the past, and finally new instruments for their maintenance should be developed.

\section{Public involvement}

There are different historical preconditions for public involvement. One essential issue to mention is that in many countries in Europe the use of the landscape for outdoor recreation and access to nature is accepted, but what this access means is explained differently; moreover it can vary when aiming for hiking, fishing or hunting.

In the Netherlands the approach dominated by nature and landscape-conservation authorities in the implementation phase has turned the debates in on itself instead of broadening out the debates towards network planning and co-operation with other actors in the field (Lammers and Van Zadelhoff 1996). The Danish counties have so far also had difficulties in co-operation with actors involved on the local level. In Flanders the failure to broaden out the values has led to strong political opposition in the phase of implementation (De Blust, Paelinckx and Kuijken 1995). It should be an important lesson for the next century that development of the new European landscapes and especially the multifunctional landscape linkages as greenways and ecological corridors cannot be done without public involvement. It is the general public that is the support for the future. Of course the views of the general public might differ from that of the scientist or the planner; but that is part of the game.

The whole territory of Europe is diverse in natural conditions, regional development, administration, regulation, and protection of nature. In some countries a national centralistic top-down approach concerning landscape planning and nature conservation seems to be a well-functioning system. In other countries a unified national approach will be hard to achieve and maybe it would not have any practical sense. In Germany most of the planning responsibilities are with the regions, the Länder. In Russia the land comprises such a huge and partly unknown diversity concerning both natural and cultural features that a national approach would be unachievable. In general, landscape planning and nature-conservation management is based on a decentralized framework. Spain, Italy, Denmark and Germany are as well examples of mainly decentralized approaches. In a number of other countries (UK, The Netherlands) a decentralization process is ongoing or has recently been established. The consequence of the decentralized position of landscape planning and landscape management in Europe includes that international co-operation is not only a matter of countries, but also of regions: Länder, provinces, districts, cantons, autonomous regions and Amte. This makes landscape planning diverse and co-operation on common European goals more complex and needed. 


\section{Conclusion}

For the future development of European landscapes as a strategy for developing and maintaining multifunctionality we can conclude that implementation of landscape linkages is a substitute for natural linkages. It is the only possibility in Europe to maintain ecological connectivity over larger distance. Natural migration is hampered in many parts of Europe and man-made constructions replace them in many cases.

Regional history has influenced not only the cultural aspects of landscapes, but also the ecological diversity. Reconstructing European linkages should not only take into account the large-scale structures and ecosystems such as mountain ranges, wetlands, forests and rivers and small scale structures such as hedgerows, ponds, stonewalls and small forests. They represent in many parts of Europe the landscape diversity and the biological diversity. Landscape construction is therefore not simply the making of landscape elements. It is also the reconstruction of biodiversity, which is much more complex as it does not return so easily once destroyed.

In many places in Europe reconstruction of landscapes is ongoing. We can learn much from European experiences and exchanges; therefore it is important to exchange and share experiences and disseminate results. To link the different aspects of landscape planning and the conservation of landscape diversity requires interdisciplinary research programmes. It also requires European communication between regions, as the responsibility for landscapes and nature conservation is in most countries decentralized towards regions. This is complex but also challenging.

\section{References}

Bischoff, N.T. and Jongman, R.H.G., 1993. Development of the rural areas in Europe: the claim for nature. SDU uitgeverij, Den Haag. Preliminary and Background Studies no. V79.

Bouwma, I.M., Jongman, R.H.G. and Butovsky, R.O. (eds.), 2002. Indicative map of the Pan-European ecological network for Central and Eastern Europe: technical background document. European Centre for Nature Conservation ECNC, Tilburg. ECNC Technical Report Series. [http://www.ecnc.nl/doc/ecnc/publicat/PEEN\%20Report\%202002.pdf]

De Blust, G., Paelinckx, D. and Kuijken, E., 1995. The green main structure of Flanders: the development and implementation of an ecological network. Landschap, 12 (3), 89-98.

Dirks, P. and Terpstra, S., 1995. Landschapsoecologische vergelijking van Twente en Niedersachsen: een grensgeval. Scriptie, Landbouwuniversiteit Wageningen.

Fry, G. and Gustavsson, R., 1996. Testing landscape design principles: the landscape laboratory. In: Jongman, R.H.G. ed. Ecological and landscape consequences of land use change in Europe. European Centre for Nature Conservation ECNC, Tilburg, 143-154. ECNC Publication Series on Man and Nature no. 2.

Goriup, P.D. and Schulz, H., 1990. Conservation management of the white stork: an international opportunity. International Council for Bird Preservation, Cambridge. ICBP Study Report no. 37.

Greuter, W., 1979. The origin and evolution of island flora as exemplified by the Aegean Archipelago. In: Bramwell, D. ed. Plants and islands. Academic Press, London, 87-106.

Hanski, I., Poyry, J., Pakkala, T., et al., 1995. Multiple equilibria in metapopulation dynamics. Nature, 377 (6550), 618-621. 
Harris, L.D., 1984. The fragmented forest: island biogeography theory and the preservation of biotic diversity. University of Chicago Press, Chicago.

Ibelings, H., 1999. Autolandschap. In: Kolen, J. and Lemaire, T. eds. Landschap in meervoud: perspectieven op het Nederlandse landschap in de 20ste/21ste eeuw. Jan van Arkel, Utrecht, 49-56.

Jongman, R.H.G., 1992. Vegetation, river management and land use in the Dutch Rhine floodplains. Regulated Rivers, 7 (3), 279-289.

Jongman, R.H.G. and Leemans, J.A.A.M., 1982. Vegetatieonderzoek Gelderse uiterwaarden. Provincie Gelderland, Arnhem.

Lammers, G.W. and Van Zadelhoff, F.J., 1996. The Dutch ecological network. In: Nowicki, P., Bennet, G., Middleton, D., et al. eds. Perspectives for ecological networks. European Centre for Nature Conservation ECNC, Tilburg, 101-113. ECNC Publications Series on Man and Nature no. 1.

Lovelock, J.E., 1979. Gaia, a new look at life on earth. Oxford University Press, Oxford.

Lucas, P. and Van Oort, G.M.R.A., 1993. Dynamiek in een stadsrandzone: werken en wonen in de stadsrandzone van de agglomeratie Utrecht $=$ Dynamics in a rural-urban fringe: working and living on the edge of the city of Utrecht. Faculteit Ruimtelijke Wetenschappen, Rijksuniversiteit Utrecht, Utrecht. Nederlandse Geografische Studies no. 154.

Runemark, H., 1969. Reproductive drift, a neglected principle in reproductive biology. Botaniska Notiser, 122, 90-129.

Searns, R.M., 1995. The evolution of greenways as an adaptive urban landscape form. Greenways: special issue of Landscape and Urban Planning, 33 (1/3), 65-80.

Smith, D.J., in press. Impacts of roads on ecological networks and integration of conservation and transportation planning: Florida as a case study. In: Jongman, R.H.G. and Pungetti, G.P. eds. Ecological networks: concepts methods and implementations. Cambridge University Press, Cambridge.

Stebbins, G.L. and Major, J., 1965. Endemism and speciation in the California flora. Ecological Monographs, 35 (1), 1-35.

Van Beusekom, F., 1999. Landschap in Nederland: Verkade of McDonald's? In: Kolen, J. and Lemaire, T. eds. Landschap in meervoud: perspectieven op het Nederlandse landschap in de 20ste/21ste eeuw. Jan van Arkel, Utrecht, 161175. 